\title{
PEMANFAATAN SNELLEN CHART OLEH GURU-GURU UKS UNTUK DETEKSI DINI GANGGUAN REFRAKSI MATA PADA ANAK-ANAK USIA SEKOLAH DASAR
}

\section{SNELLEN CHART USE BY UKS TEACHERS FOR EARLY DETECTION OF CHILDREN EYE REFRACTIVE ERRORS ON PRIMARY SCHOOL AGE}

\author{
Oleh: \\ Zayadi Zainuddin, Arif Ikhwandi, Mardhatilah Marsa \\ zay_adi@yahoo.co.id
}

\begin{abstract}
Eye refractive errors that are not handled seriously will affect the intellectual development of children. The learning process is stunted children can affect the quality, creativity, and productivity in the productive age. Early detection of refractive errors can be done with a simple eye. Its objective is to equip UKS teachers in practicing the use of Snellen chart as an ongoing screening program for the prevention of risks of children with visual impairments in children of primary school age. The method of this activity is done by providing direct training to the teachers, especially primary school UKS teachers to use the Snellen chart. Training activities and practice the use of Snellen chart for UKS teachers of primary schools in the district Taba Penanjung place smoothly as expected. Need governments to elementary schools were able to detect and follow up on children who experience eye refractive errors early on an ongoing basis.
\end{abstract}

Keywords: refraction, Snellen chart, training

\section{PENDAHULUAN}

Penyebab tersering kebutaan di dunia adalah katarak dan gangguan refraksi mata. Berdasarkan hasil Riskesdas tahun 2013 prevalensi kebutaan nasional sebesar 0,4\%, prevalensi kebutaan penduduk umur 6 tahun keatas tertinggi ditemukan sebesar 1,1\% (untuk Bengkulu sebesar 0,3\%) dan prevalensi severe low vision penduduk umur 6 tahun keatas sebesar 0,9 persen (untuk bengkulu sebesar 0,7\%). Di Indonesia, dari 66 juta anak usia sekolah (5-19 tahun), 10\% mengalami gangguan akibat kelainan refraksi. Angka prevalensi severe low vision dan kebutaan tersebut cenderung lebih tinggi di perdesaan dibandingkan daerah perkotaan. Angka pemakaian kacamata koreksi pun masih rendah, yaitu 12,5\% (untuk bengkulu sebesar 3,7\%). Begitu juga proporsi penduduk yang mempunyai kaca mata atau lensa kontak di perkotaan sekitar dua kali lebih banyak dibandingkan di perdesaan (Riset Kesehatan Dasar, 2013).

Kelainan refraksi mata yang tidak ditangani secara sungguh-sungguh, akan berpengaruh pada perkembangan kecerdasan anak. Proses belajar anak yang terhambat, dapat mempengaruhi mutu, kreativitas, dan produktivitas pada usia produktif kelak. Deteksi dini kelainan refraksi mata dapat dilakukan dengan sederhana. Guru-guru sekolah dasar 
dapat dilibatkan dalam proses penjaringan kasus kelainan refraksi mata dengan menggunakan Snellen chart. Harapannya, deteksi anak dengan gangguan penglihatan dapat lebih cepat dan ditangani dengan baik (Fachrian D, dkk, 2009; Ilyas S, 1991).

Menurut survei awal di Kecamatan Taba Penanjung kabupaten Bengkulu Tengah memiliki 19 sekolah dasar dengan jumlah murid dari SD sebanyak 379 orang, dimana jumlah anak laki-laki sebanyak 185 orang serta anak perempuan sebanyak 194 orang. Berdasarkan informasi dari beberapa kepala sekolah dasar dan guru belum ada suatu tindakan skrining atau deteksi dini gangguan penglihatan anak sekolah dasar dari pelayanan kesehatan setempat. Padahal mereka juga sering menemukan anak murid yang mengalami gangguan penglihatan pada saat proses belajar mengajar di dalam kelas namun hanya menyerahkan permasalahn gangguan penglihatan tersebut kepada petugas kesehatan maupun orang tua murid.)

\section{METODE PENGABDIAN}

Sasaran untuk pemanfaatan Snellen chart ini adalah guru-guru sekolah dasar terutamanya guru yang bertanggungjawab pada unit kegiatan sekolah (UKS). Guru UKS memiliki peranan penting dalam pencegahan terjadinya gangguan kesehatan yang terjadi pada lingkungan sekolah. Guru UKS juga memiliki nilai strategis sehingga diharapkan dapat menyebarluaskan penerapan teknologi ini pada pada guru di lingkungan sekolah masingmasing. Setelah penyebarluasan teknologi ini, diharapkan juga pada guru dapat selalu melakukan penapisan atau skrining berkelanjutan sehingga menemukan secara dini berbagai kondisi gangguna penglihatan pada anak sekolah dasar.

Metoda kegiatan ini dengan memberikan pelatihan langsung pada guru-guru sekolah dasar terutama guru UKS untuk menggunakan Snellen chart. Pelatihan ini akan dilakukan dengan berbagai metoda belajar yaitu:

1. Kuliah interaktif mengenai gangguan penglihatan pada anak usia sekolah dasar

2. Diskusi tentang kasus-kasus terkait gangguan penglihatan pada anak usia sekolah dasar

3. Praktik keterampilan penggunaan snellen chart sebagai pendeteksi dini gangguna penglihatan pada anak usia sekolah dasar

\section{HASIL DAN PEMBAHASAN}

Kesehatan indera penglihatan merupakan syarat penting untuk meningkatkan kualitas sumber daya manusia Indonesia yang cerdas, produktif, maju, madiri dan sejahtera lahir batin. Terlebih bagi anak-anak usia sekolah dasar yang masih dalam masa menempuh pendidikan awal, tentulah sangat mengganggu dalam belajar jika anak-anak tersebut mengalami kelainan refraksi mata. Di lain pihak kelainan tersebut tidak dapat terdeteksi dini mengingat ketidakpekaan orang tua dalam melakukan pemeriksaan mata ke tenaga kesehatan. Hal ini mengakibatkan anak-anak tersebut dapat mengalami penurunan dalam kemampuan menyerap pelajaran yang pada akhirnya akan berimbas pada menurunnya 
kemampuan intelektualitasnya (Ilyas, 1991).

Jika hal ini didiamkan, maka dapat berimbas pada menurunnya kualitas SDM generasi muda Indonesia. Menurunnya kualitas SDM generasi muda akan berpengaruh pada daya saing bangsa ini, terutama di era globalisasi saat ini. Bisa dipastikan Indonesia akan terus tertinggal oleh bangsa lain. Saat ini, di Indonesia ada sekitar 6,6 juta anak-anak sekolah yang menderita kelainan refraksi (kelainan mata, seperti minus dan silinder) dan hanya sedikit saja yang bisa menggunakan kaca mata. Lagi-lagi karena ketidakmampuan dari orang tuanya untuk membelikan kaca mata yang relatif mahal (Fachrian, dkk, 2009).

Pemerintah Indonesia telah mencanangkan program WHO Vision 2020 - The Right to Sight di Indonesia. Program ini merupakan inisiatif global untuk menanggulangi gangguan penglihatan dan kebutaan yang sebenarnya dapat dicegah/direhabilitasi. Tujuan pencanangan program ini adalah pemberian hak bagi setiap warga negara Indonesia untuk mendapatkan penglihatan yang optimal. Kebutaan menjadi salah satu penyebab ketidakmandirian ekonomi dan akhirnya menjadi beban bagi keluarga dan masyarakat. Inilah yang menyebabkan kebutaan dan kelainan pada indera penglihatan menjadi sebuah masalah sosial. Karena sudah menjadi masalah sosial, maka masalah ini tidak bisa hanya ditanggulangi oleh pemerintah saja, tapi perlu peran serta masyarakat, baik secara personal maupun institusi yang berkontribusi baik dengan berkolaborasi satu sama lain ataupun sendiri-sendiri (Fachrian, dkk, 2009).

Telah dilakukan pelatihan untuk guru-guru yang bertangguung jawab dengan usaha kesehatan sekolah (UKS) pada sekolah dasar di kecamatan Taba Penanjung Kabupaten Bengkulu Tengah. Pelatihan ini dilakukan selama 1 hari bertempat di puskesmas Taba Teret yang merupakan UPTD kesehatan yang menaungi wilayah kecamatan Taba Penanjung. Setelah para guru melakukan pelatihan ini diharapkan peserta guru UKS mensosialisasikannya dengan para guru lainnya dan melakukan penerapan snellen chart ini pada usaha kesehatan sekolahnya masing-masing. Hal ini sangat bermanfaat dalam melakukan penapisan atau skrining terkait kasus gangguan penglihatan pada murid sekolah dasar yang dinaunginya. Keberlanjutan dari porgram ini adalah melakukan monitoring penerapan snellen chart ini pada setiap sekolah untuk diimplemetasikan sehingga bersamasama dengan puskesmas melakukan upaya skrining dengan tujuan menemukan kasus gangguan refraksi mata lanjut pada anak sekolah dasar untuk segera dirujuk ke puskemas terdekat dan melakukan upaya pencegahan oleh pihak sekolah sendiri.

\section{KESIMPULAN DAN SARAN}

Kegiatan pelatihan dan praktek pemanfaatan snellen chart untuk guru-guru UKS sekolah dasar di kecamatan Taba Penanjung berlangsung dengan lancar seusai yang diharapkan. Seluruh peserta antusias dan aktif mengikuti setiap tahapan kegiatan. Kegiatan ini dapat dilanjutkan dengan menerapkan penggunaan snellen chart ini pada tingkat sekolah lanjutan tingkat atas dan kader-kader masyarakat yang peduli dengan peningkatan derajat kesehatan masyarakat. Selain itu, perlu diupayakan sinergitas puskesmas yang menaungi 
sekolah-sekolah yang berada di wilayah kerjanya untuk memonitoring kegiatan ini maupun menindaklanjuti anak-anak yang mengalami kelainan refraksi mata.

\section{DAFTAR PUSTAKA}

Riset Kesehatan Dasar, 2013, Diakses dari

http://depkes.go.id/downloads/riskesdas2013/Hasil\%20Riskesdas\%202013.pdf pada tanggal 1 April 2014.

Fachrian D., Rahayu A.B., Naseh A.J., dkk., 2009, Prevalensi Kelainan Tajam Penglihatan pada Pelajar SD “X” Jatinegara Jakarta Timur, Majalah Kedokteran Indonesia, Vol 59 (6), FKUI, Jakarta, pp 1-10.

Ilyas, S., 1991, Tajam pengtihatan dan Kelainan Refraksi, Penuntun Ilmu Penyakit Mata. 